\title{
Effects of the faecal stream and stasis on the ileal pouch mucosa
}

\author{
H J de Silva, P R Millard, N Soper, M Kettlewell, N Mortensen, D P Jewell
}

\begin{abstract}
This study aimed to investigate the effects of the faecal stream and stasis on the mucosa of ileal pouches. Nine patients were followed up. Two pouch biopsy specimens were obtained from each at the time of pouch formation, ileostomy closure, and three, six, and 12 months after operation. None developed pouchitis. Two pouch biopsy specimens each were also obtained from 20 patients (six with pouchitis), whose pouches had been functioning for at least a year and in whom pouch evacuation was assessed by radioisotope labelled artificial stool. Biopsy specimens were assessed for the degree of acute and chronic inflammation, mucin type (high iron diaminealcian blue stain), a morphometric index of villous atrophy (villous height:total mucosal thickness), and crypt cell proliferation (using the monoclonal antibody Ki67). Mean values from the two biopsy specimens were obtained for each parameter. After three months of pouch function, the scores for acute and chronic inflammation, the degree of sulphomucin, and crypt cell proliferation were significantly higher, and the index of villous atrophy was significantly lower (indicating a greater degree of villous atrophy), than at pouch formation or at ileostomy closure. The values at pouch formation and ileostomy closure were similar. For all parameters, the changes seen at six and 12 months were not significantly different from those at three months. There was no significant correlation between the efficiency of pouch evacuation and any of the mucosal changes. It is concluded that exposure to the faecal stream is necessary for changes to take place in the pouch mucosa, although the amount of stasis, as measured by radioisotopic evacuation studies, seems to be irrelevant. The mucosal changes occur soon after ileostomy closure and then remain stable for at least one year.
\end{abstract}

Departments of Gastroenterology, Surgery, Histopathology and Nuclear Medicine, John Radcliffe Hospital, Oxford

$\mathrm{H}$ J de Silva

P R Millard

N Soper

M Kettlewell

N Mortensen

D P Jewell

Correspondence to: Dr D P Jewell, Gastroenterology Unit, Radcliffe Infirmary, Woodstock Road, Oxford OX2 6HE.

Accepted for publication 31 December 1990
The faecal stream and stasis probably play a major role in the pathogenesis of pouchitis because acute macroscopic inflammation is rare in both defunctioned pouches and unobstructed conventional ileostomies. ${ }^{1-4}$ It is also likely that the histological changes which occur in functioning ileal pouches are a response to this new luminal environment (faecal stasis) ${ }^{35-9}$ since similar degrees of histological change are only rarely seen in conventional ileostomies where there is no stasis. ${ }^{8}$ Some of the changes, such as villous atrophy, crypt hyperplasia, and a mild to moderately severe inflammatory cell infiltrate in the lamina propria (consisting mainly of chronic inflammatory cells), can occur even in pouches without pouchitis ${ }^{6810-13}$ and seem to be independent of the original diagnosis of ulcerative colitis or familial adenomatous polyposis. ${ }^{613}$ Nevertheless, a number of studies investigating the efficiency of pouch evacuation, using both radioisotopic and non-isotopic artificial stools, have failed to find an association between the efficiency of evacuation and either pouchitis ${ }^{1011}$ it or the severity of the histological changes in the pouch mucosa ${ }^{8} 10$ is

The aims of this study were firstly, to investigate the early and delayed effects of the faecal stream on the pelvic ileal pouch mucosa by making serial observations over a period of one year from the time of pouch formation, and secondly to relate mucosal changes to efficiency of pouch emptying of an artificial stool.

\section{Patients and tissues}

Nine patients with pelvic ileal pouches (seven men, median age 30 years (range 19-54)) were followed up for a period of 12 months from the time of their pouch formation. All of them had originally had ulcerative colitis. Two pouch biopsy specimens, taken at least $10 \mathrm{~cm}$ from the anal verge, were obtained at the time of pouch formation, at ileostomy closure (median 14 weeks (range 7-28) after pouch formation), and then at three, six, and 12 months after operation from each patient. None of the patients developed pouchitis during the follow up period or were taking medication other than antidiarrhoeal drugs (loperamide or diphenoxylate) throughout the 12 months.

Two mucosal biopsy specimens, taken at least $10 \mathrm{~cm}$ from the anal verge, were also obtained from 20 patients with pelvic ileal pouches (15 men, median age 32 (range 22-56)) who consented to pouch evacuation studies. All of them had previously had ulcerative colitis, and the pouches had been functioning for a median 28 months (range 13-72). Six had pouchitis at the time of the study but none of them had an anastomotic stricture. The biopsy specimens were taken on the day pouch evacuation was assessed. All medication was withheld, with the patients consent, until after the evacuation studies.

Each of the biopsy specimens was divided into two. One half was fixed in formalin and embedded in paraffin and the other was immediately snap frozen in isopentane in liquid nitrogen and stored in liquid nitrogen until sectioning.

\section{Methods}

ASSESSMENT OF POUCH EVACUATION

Pouch evacuation was assessed using a scinti- 
graphic technique that was a slight modification of the method described by O'Connell et al. ${ }^{16}$ The patients were fasted for eight hours. They were asked to empty the pouch as completely as possible and any residual faeces was drained via a sigmoidoscope immediately before the study. The artificial stool used was a $7 \cdot 5 \%$ suspension of aluminium magnesium silicate in water, labelled with ${ }^{99 m} \mathrm{Tc}$ diethylenetriamine-penta-acetate (DTPA). The artificial stool was instilled into the pouch via a transanal tube until the patient developed a constant feeling of impending defaecation, which was taken as the maximum tolerated pouch capacity. An IGE400T $\gamma$ camera interfaced with a NUD512+ computer system was used for imaging. Three minute static posterior and right lateral images of the pelvis were obtained after the patient was seated on a commode but before evacuation. The patient was then asked to defaecate. After spontaneous evacuation the patient was allowed assisted evacuation if this was their usual practice. This consisted of abdominal wall pressure, change in posture or use of a catheter. After assisted evacuation ('total' evacuation), three minute static posterior and right lateral images of the pelvis were repeated. Pouch evacuation was calculated by counting the activity in the images taken before and after evacuation. Total pouch evacuation was expressed as a percentage of the dose of radioactivity instilled.

\section{HISTOLOGY, MUCOSAL MORPHOMETRY, AND MUCIN HISTOCHEMISTRY}

Serial sections of formalin fixed paraffin embedded tissue $(4 \mu)$ were stained with haematoxylin and eosin (H\&E) and high iron diamine-alcian blue (HID-AB). The H\&E stained sections were scored on a scale of 0 (absent) to 3 (severe) for the degree of acute and chronic inflammation. The same sections were used for mucosal morphometry. Linear measurements of total mucosal

TABLE I Serial observations of changes in the pouch mucosa in nine patients - inflammation and changes in mucin. (Values are expressed as median and range.)

\begin{tabular}{|c|c|c|c|c|c|}
\hline Score & $\begin{array}{l}\text { Pouch } \\
\text { formation }\end{array}$ & $\begin{array}{l}\text { Ileostomy } \\
\text { closure }\end{array}$ & $\begin{array}{l}3 \\
\text { Months }\end{array}$ & $\stackrel{6}{\text { Months }}$ & 12 \\
\hline $\begin{array}{l}\text { Acute inflammation } \\
\text { Chronic inflammation } \\
\text { Mucin type } \neq\end{array}$ & $\begin{array}{l}0(0) \\
0(0-1) \\
1(1)\end{array}$ & $\begin{array}{l}0(0-1) \\
0(0-2) \\
1(1)\end{array}$ & $\begin{array}{l}1.0(0-1 \cdot 5)^{\star} \\
1.5(0-2)^{\star} \\
1.5(1-2)^{\star}\end{array}$ & $\begin{array}{l}0.5(0-1.5)^{\star} \\
1.5(0-2)^{\star} \\
1.5(1-2 \cdot 5)^{\star}\end{array}$ & $\begin{array}{l}1 \cdot 0(0-2)^{\star} \\
1 \cdot 5(0.5-2 \cdot 5)^{\star} \\
1 \cdot 5(1-2 \cdot 5)^{\star}\end{array}$ \\
\hline
\end{tabular}

${ }^{\star} \mathrm{p}<0.05$ when compared with pouch formation or ileostomy closure.

† Score; $0=$ none, $1=$ mild, $2=$ moderate, $3=$ severe.

$\ddagger$ Mucin types; 1 = predominantly sialomucin, $2=$ mixed, 3 =predominantly sulphomucin

TABLE II Serial observations of changes in the pouch mucosa in nine patients - mucosal morphometry and crypt cell proliferation. (Values are expressed as median (range).)

\begin{tabular}{|c|c|c|c|c|c|}
\hline & $\begin{array}{l}\text { Pouch } \\
\text { formation }\end{array}$ & $\begin{array}{l}\text { Ileostomy } \\
\text { closure }\end{array}$ & $\begin{array}{l}3 \\
\text { Months }\end{array}$ & $\stackrel{6}{\text { Months }}$ & $\begin{array}{l}12 \\
\text { Months }\end{array}$ \\
\hline Villous height $(\mu \mathrm{m})$ & $\begin{array}{l}280 \\
(200-480)\end{array}$ & $\begin{array}{l}264 \cdot 6 \\
(181 \cdot 3-357 \cdot 5)\end{array}$ & $\begin{array}{l}183 \cdot 4^{\star \star} \\
(147 \cdot 6-275)\end{array}$ & $\begin{array}{l}162 \cdot 5^{\star \star} \\
(74 \cdot 3-290)\end{array}$ & $\begin{array}{l}139 \cdot 6^{\star \star} \\
(75-259 \cdot 6)\end{array}$ \\
\hline Crypt depth $(\mu \mathrm{m})$ & $\begin{array}{l}209 \\
(112 \cdot 5-253)\end{array}$ & $\begin{array}{l}196 \cdot 3 \\
(125-256 \cdot 2)\end{array}$ & $\begin{array}{l}283 \cdot 3^{\star} \\
(150-399 \cdot 6)\end{array}$ & $\begin{array}{l}291 \cdot 7 \star \\
(166 \cdot 7-445)\end{array}$ & $\begin{array}{l}268 \cdot 8^{\star} \\
(173 \cdot 7-400)\end{array}$ \\
\hline $\begin{array}{l}\text { Total mucosal thickness } \\
(\mu \mathrm{m})\end{array}$ & $\begin{array}{l}512 \cdot 5 \\
(312 \cdot 5-690)\end{array}$ & $\begin{array}{l}445 \cdot 9 \\
(387 \cdot 5-550)\end{array}$ & $\begin{array}{l}466 \cdot 7 \\
(350-556 \cdot 3)\end{array}$ & $\begin{array}{l}464 \cdot 6 \\
(325-530)\end{array}$ & $\begin{array}{l}429 \cdot 2 \\
(325-625)\end{array}$ \\
\hline $\begin{array}{l}\text { Villous height:total } \\
\text { mucosal thickness }\end{array}$ & $\begin{array}{l}0.62 \\
(0.54-0.7)\end{array}$ & $\begin{array}{l}0.59 \\
(0.41-0.68)\end{array}$ & $\begin{array}{l}0 \cdot 38 \star \star \\
(0 \cdot 28-0 \cdot 58)\end{array}$ & $\begin{array}{l}0 \cdot 38^{\star \star} \\
(0 \cdot 16-0.62)\end{array}$ & $\begin{array}{l}0.35^{\star \star} \\
(0 \cdot 16-0.6)\end{array}$ \\
\hline Crypt cell proliferation $\dagger$ & $\begin{array}{l}17 \cdot 4 \\
(13 \cdot 3-27 \cdot 6)\end{array}$ & $\begin{array}{l}19 \cdot 0 \\
(10 \cdot 5-29 \cdot 3)\end{array}$ & $\begin{array}{l}31 \cdot 2^{\star \star} \\
(21 \cdot 8-39 \cdot 6)\end{array}$ & $\begin{array}{l}33 \cdot 6^{\star \star} \\
(23 \cdot 4-42)\end{array}$ & $\begin{array}{l}35 \cdot 6 \star \star \\
(23 \cdot 2-42 \cdot 7)\end{array}$ \\
\hline
\end{tabular}

${ }^{\star} \mathrm{p}<0.05 ;{ }^{\star \star} \mathrm{p}<0.01$; when compared with pouch formation or ileostomy closure.

tCrypt cell proliferation is expressed as the percentage of Ki67 positive epithelial cell nuclei per crypt. thickness and crypt depth were made using a celebrated eye piece (Leitz) as described previously. ${ }^{17} 18$ Villous height and an index of villous atrophy (villous height:total mucosal thickness) were then calculated for each section. ${ }^{817}$ The HID-AB stained sections were scored for sialomucin (blue) predominance (score 1), a mixed mucin pattern (score 2), or sulphomucin (brown) predominance (score 3).

\section{CRYPT CELL PROLIFERATION}

Crypt cell proliferation in pouches was assessed by an immunohistochemical method, using the monoclonal antibody $\mathrm{Ki67}$, as described previously. ${ }^{19}$ Cryostat sections of snap frozen tissue $(5 \mu)$ were stained with the monoclonal antibody using a three stage immunoperoxidase procedure. Crypt cell proliferation was expressed as a percentage of $\mathrm{Ki} 67$ positive epithelial cell nuclei per total number of crypt epithelial cell nuclei. ${ }^{19}$

All sections were coded, and assessments were made blindly. For each patient, mean values were obtained from the two biopsy specimens for each parameter. In the 20 patients whose pouch evacuation was assessed, the mucosal changes were correlated to the percentage total evacuation of the artificial stool by the pouch

\section{STATISTICAL ANALYSIS}

Grouped data were expressed as median and range. Differences between measurements were assessed by the Mann-Whitney $U$ test. The significance of correlation was determined by the Spearman rank correlation test. Statistical significance was taken as $\mathrm{p}<0.05$.

\section{Results}

\section{SERIAL OBSERVATIONS}

The ileal mucosa was not macroscopically inflamed in any of the nine patients during the follow up period. The results are summarised in Tables I and II. The values for any parameter were not significantly different between specimens obtained at pouch formation and ileostomy closure. However, the scores for acute and chronic inflammation, the score for mucin type (a higher score indicating a greater amount of sulphomucin), crypt depth, and crypt cell proliferation were all significantly higher, while villous height and the index of villous atrophy (villous height:total mucosal thickness) were significantly lower (indicating a greater degree of villous atrophy) in functioning pouches (at three, six, and 12 months) when compared with values obtained either at pouch formation or ileostomy closure. There was no significant difference in the values for any of the parameters between specimens obtained at three, six, or 12 months. There was no significant difference in total mucosal thickness during the follow up period, indicating that villous atrophy, when it occurred, was always accompanied by crypt hyperplasia.

Although, overall, there were no significant differences in any of the parameters between 
specimens obtained at pouch formation and ileostomy closure, two biopsy specimens taken from two patients at ileostomy closure showed moderate to severe degrees of acute and chronic inflammation, and partial villous atrophy. Perl's stain for iron was negative in both sections. Neither of the two patients had any symptoms nor subsequently developed pouchitis.

\section{RELATION BETWEEN EFFICIENCY OF POUCH EVACUATION AND MUCOSAL CHANGES}

The clinical diagnosis of pouchitis was confirmed histologically in all six patients. There was no significant correlation between the percentage total evacuation of the artificial stool from the pouch and either the scores for acute $\left(r_{s}=-0.05\right.$, $\mathrm{p}=0.84)$ or chronic inflammation $\left(\mathrm{r}_{\mathrm{s}}=-0.14\right.$, $\mathrm{p}=0.57)$, score for mucin type $\left(\mathrm{r}_{\mathrm{s}}=-0.22, \mathrm{p}=\right.$ $0 \cdot 36$ ), the index of villous atrophy (villous height: total mucosal thickness) $\left(r_{s}=0.002, p=0.96\right)$, or crypt cell proliferation $\left(r_{s}=-0 \cdot 11, p=0.65\right)$. The correlations remained non-significant even when data from the patients with pouchitis were excluded.

\section{Discussion}

The formation of an ileal pouch results in stasis of ileal contents and its colonisation with a microbial flora, mainly anaerobic, that resemble the flora of normal faeces. ${ }^{581520-23}$ It has been suggested that this change in the luminal environment may be responsible for the mucosal changes seen in functioning pouches. ${ }^{35-9}$ These mucosal changes could be mediated by bacterial overgrowth per se, or its effects on either luminal short chain fatty acid concentrations or the pouch bile acid composition, producing potentially toxic concentrations of secondary and deconjugated bile acids. ${ }^{382426}$

Mucosal biopsy specimens from functioning pouches commonly show villous atrophy, crypt hyperplasia, increased crypt cell proliferation, mucosal inflammation, and a change in mucin type from small bowel type sialomucin to a large bowel type sulphomucin..$^{5-7101113}$ The present study is the first to follow patients prospectively from the time of pouch formation and investigate all these parameters in serial biopsy specimens including those obtained at pouch formation and at ileostomy closure. It seems that exposure to the faecal stream is necessary for mucosal changes to take place.

Philipson et $a l,{ }^{5}$ in a study of six patients followed up after ileostomy closure, have shown that the morphological changes (villous atrophy and crypt hyperplasia), together with increased crypt cell turnover (determined by the number of mitoses per crypt), were well established as early as one month after ileostomy closure and then remained fairly stable over a two year period. Lerch et $a l^{12}$ found no significant differences in villous height or crypt depth between pouch biopsy specimens obtained at two and up to three years after ileostomy closure, and Moskowitz et al,,$^{10}$ in a retrospective study, found no significant differences between the scores for acute or chronic inflammation at less than six months and 36 to 42 months after ileostomy closure. None of these studies has presented any information about the state of either the ileum at pouch formation or the pouch at ileostomy closure. Lack of this data is important because histological and histochemical changes are sometimes seen in both the terminal ileum and pouches before ileostomy closure in patients with ulcerative colitis. ${ }^{627}$ Nevertheless, the findings of these studies do not conflict with the results of the present study and indicate that changes in the pouch mucosa which occur in response to the faecal stream occur soon after ileostomy closure, after which a 'steady state' seems to develop. In contrast, the results of Go et $a l^{7}$ seem to suggest that the severity of the mucosal changes increases gradually with the time elapsed since surgery. However, this was a poorly controlled study and the results were not based on serial biopsy specimens but on single specimens obtained from different patients whose pouches had been functioning for variable lengths of time.

As stasis is the major functional difference between conventional ileostomies and pouches, it is tempting to implicate faecal stasis in the pathogenesis of the mucosal changes occurring in pouches. However, this study, in agreement with others, ${ }^{810}$ is has shown no correlation between the efficiency of pouch evacuation and any of the mucosal changes studied. Therefore, although it seems that the faecal stream and stasis are important 'threshold' factors for the development of mucosal changes, the amount of stasis seems to be irrelevant. There is further indirect evidence for the hypothesis that mucosal changes in ileal pouches are the result of exposure to the faecal stream, stasis, and bacterial overgrowth. O'Byrne et $a l^{28}$ showed that histological and histochemical (mucin) changes, similar to those observed in pouches, could be induced in segments of ileum transposed to the distal colon in rats. Villous atrophy, crypt hyperplasia, and an increased crypt cell turnover have been shown in both experimental small intestinal self filling blind loops in rats ${ }^{29}$ and in syndromes of small intestinal bacterial overgrowth in man..$^{30-32}$ Furthermore, these histological changes are considerably less in experimental germ free mice compared with animals with a conventional flora. ${ }^{33}$

In the present study, histological changes were seen in two pouch biopsy specimens before ileostomy closure, although the pouches were not macroscopically inflamed. Neither of the two patients subsequently developed pouchitis. Pouch inflammation before ileostomy closure has previously been reported. ${ }^{27}{ }^{34}$ The aetiology of this rare condition may be different to that of pouchitis because faecal diversion by means of a loop ileostomy has been advocated in the management of severe pouchitis that does not respond to medical therapy. ${ }^{35}{ }^{36}$ Possible mechanisms for the development of this type of pouch inflammation may include chronic ischaemia ${ }^{49}$ but there were no characteristic histological features, such as iron laden macrophages or mucosal fibrosis, ${ }^{37}$ to suggest this diagnosis in the two patients in this study. Another possibility is a mechanism similar to that occurring in defunctioned colitis. 
Villous atrophy and crypt hyperplasia, which are seen in functioning pouches, are closely associated with increased crypt cell proliferation. ${ }^{519}$ Fears have been aroused that a sustained high degree of epithelial cell proliferation may increase the risk of neoplasia in ileal pouches. ${ }^{9}$ However, although the development of an adenocarcinoma within an ileal pouch (thought to have arisen from a cuff of rectal mucosa inadvertently left behind during pouch surgery) has recently been reported, ${ }^{38}$ neither epithelial dysplasia nor malignancy have yet been encountered in the pouch mucosa. ${ }^{69-12} \mathrm{~A}$ long term follow up study from Goteborg, Sweden (a continuation of the study by Philipson et al in $1975^{5}$ ) has shown that although crypt cell turnover in pouches (determined by the number of mitoses per crypt) was increased during the first two years after ileostomy closure, it had returned to values seen in normal ileum after six to 10 years $\mathrm{s}^{39}$ and remained normal 16 to 20 years $\mathrm{y}^{42}$ after surgery. However, the results were not all based upon serial observations in individual patients. None of the patients from whom biopsy specimens were obtained had pouchitis, and despite the crypt cell turnover becoming normal, the villi remained significantly shorter and the number of crypt cells remained significantly increased when compared with normal ileum. These results have been interpreted as suggesting that in the long term, the pouch mucosa becomes fully adapted and is no longer hyperregenerative. This may reduce the risk for the development of dysplasia. Furthermore, the histological changes that occur in functioning pouches were found not to increase the risk of malignant transformation in the 1,2dimethylhydrazine dihydrochloride model of intestinal carcinogenesis in rats. ${ }^{+3}$ Nevertheless, very few pouches have been functioning for more than 10 years so that the late effects of pouch formation remain unknown. This stresses the need for longterm follow up with regular endoscopic and histological assessments in these patients.

$\mathrm{HJ}$ de $\mathrm{S}$ is in receipt of an Overseas Research Student award and a Wingate scholarship. We thank Caroline Prince for technical assistance.

Parts of this work have been presented at meetings of the British Society of Gastroenterology, Warwick, March 1990, an Southampton, September 1990 (Gut 1990; 31: A618 and A1168).

1 Warren R, McKittrick LS. Ileostomy for ulcerative colitis: technique, complications and management. Surg Gynecol Obstet 1951; 93: 555-67.

2 Counsell B. Lesions of the ileum associated with ulcerative colitis. Br 7 Surg 1956; 44: 276-90.

3 Scott AD, Phillips RKS. Ileitis and pouchitis after colectomy for ulcerative colitis. Br $\mathcal{F}$ Surg 1989; 76: 668-9.

4 Tytgat GNJ. Workshop. Pouchitis. Int $\mathcal{f}$ Colorectal Dis 1989 4: 205-29.

5 Philipson B, Brandberg A, Jagenburg R, Kock NG, Lager I Ahren C. Mucosal morphology, bacteriology and absorption in intra-abdominal ileostomy reservoir. Scand Gastroenterol 1975; 10: 145-53.

6 Shepherd NA, Jass JR, Duval I, Moskowitz RL, Nicholls RJ, Morson BC. Restorative proctocolectomy with ileal reservoir; pathological and histochemical study of mucosal biopsy specimens. $\mathcal{F}$ Clin Pathol 1987; 40: 601-7.

7 Go PMNYH, Lens J, Bosman FT. Mucosal alterations in the reservoir of patients with Kock's continent ileostomy. Scand f Gastroenterol 1987; 22: 1076-80.

8 Nasmuth DG, Godwin PGR, Dixon MF, Williams NS, Johnston D. Ileal ecology after pouch-anal anastomosis or ileostomy. Gastroenterology 1989; 96: 817-24. 9 Shepherd NA. The pelvic ileal reservoir: pathology and

10 Moskowitz RL, Shepherd NA, Nicholls RJ. An assessment of inflammation in the reservoir after restorative proctocolectomy with ileoanal reservoir. Int $\mathcal{f}$ Colorectal Dis 1986; 1 : 167-74.

11 O'Connell PR, Rankin DR, Weiland LH, Kelly KA. Enteric bacteriology, absorption, morphology and emptying after
ileal pouch-anal anastomosis. Br F Surg 1986; 73: 909-14.

12 Lerch MM, Braun J, Harder M, Hofstadter F, Schumpelick $\mathrm{V}$, Matern S. Postoperative adaptation of the small intestine after total colectomy and J-pouch-anal anastomosis. Dis Colon Rectum 1989; 32: 600-8.

13 de Silva HJ, Millard PR, Kettlewell M, Mortensen NJ, Prince C, Jewell DP. Mucosal characteristics of pelvic ileal pouches. Gut 1991; 32: 61-5.

14 Heppell J, Belliveau P, Taillefer R, Dube S, Derbekyan V. Quantitative assessment of pelvic ileal reservoir emptying with a semisolid radionuclide enema. Dis Colon Rectum 1987; 30: 81-5.

15 Nasmyth DG, Johnston D, Godwin PGR, Dixon MF, Smith A, Williams NS. Factors influencing bowel function after ileal pouch-anal anastomosis. Br f Surg 1986; 73: 469-73.

16 O'Connell PR, Kelly KA, Brown ML. Scintigraphic assessment of neorectal motor function. $\mathcal{f}$ Nucl Med 1986; 27: $460-4$

17 Corazza GR, Frazzoni M, Dixon MF, Gasbarrini G. Quantitative assessment of the mucosal architecture of jejunal biopsy specimens: a comparison between linear measurement, stereology, and computer aided microscopy. $\mathcal{F}$ Clin Pathol 1985; 38: 765-70.

18 Scott BB, Losowsky MS. Patchiness and duodenal-jejunal variation of the mucosal abnormality in coeliac disease and dermatitis herpetiformis. Gut 1976; 17: 984-92.

19 de Silva HJ, Gatter KC, Millard PR, Kettlewell M, Mortensen NJ, Jewell DP. Crypt cell proliferation and HLA-DR expression in pelvic ileal pouches. $\mathcal{F}$ Clin Pathol 1990; 43: express.

20 Brandberg A, Kock NG, Philipson B. Bacterial flora in intraabdominal ileostomy reservoir. Gastroenterology 1972; 63: 413-6.

21 Luukkonen P, Valtonen V, Sivonen A, Sipponen P, Jarvinen H. Faecal bacteriology and reservoir ileitis in patients operated on for ulcerative colitis. Dis Colon Rectum 1988; 31 $864-7$.

22 Go PMNYH, Van Dieijen-Visser MP, Davies BI, Lens J, Brombacher PJ. Microbial flora and bile acid metabolism in patients with an ileal reservoir. Scand $\mathcal{F}$ Gastroenterol 1988; 23: $229-36$

23 Hill MJ, Fernandez F. Workshop. Pouchitis. Int 7 Colorectal Dis $1989 ; 4: 205-29$.

24 Nasmyth DG, Johnston D, Williams NS, King RFGJ, Burkinshaw L, Brooks K. Changes in the absorption of bile acids after total colectomy in patients with an ileostomy or pouch-anal anastomosis. Dis Colon Rectum 1989; 32: 230-4.

25 Hill MJ, Owen RW. Workshop. Pouchitis. Int $\mathcal{F}$ Colorectal Dis 1989; 4: 205-29.

26 Madden MV, Farthing MJG, Nicholls RJ. Inflammation in ileal reservoirs: 'pouchitis'. Gut 1990; 31: 247-9.

27 Warren BF, Bartolo DCC, Collins CMP. Preclosure pouchitis - a new entity. F Pathol 1990; 160: 170A.

28 O'Byrne JM, O'Connell PR, Nolan N, Marks P, Tanner WA, Keane FBV. Colonic metaplasia of ileal mucosa: an experimental model. Gut 1989; 30: A1477

29 Menge H, Kohn R, Dietermann KH, Lorenz-Meyer H, Riecken EO, Robinson JWL. Structural and functional alterations in the mucosa of self-filling intestinal blind loops in rats. Clin Sci 1979; 56: 121-31.

30 Ament ME, Shimoda SS, Saunders DR, Rubin CE. Pathogenesis of steatorrhoea in 3 cases of small intestinal stasis syndrome. Gastroenterology 1972; 63: 728-47.

31 Perera DR, Weinstein WM, Rubin CE. Small intestina biopsy. Hum Pathol 1975; 6: 157-217.

32 King CE, Toskes PP. Small intestine bacterial overgrowth Gastroenterology 1979; 76: 1035-55.

33 Abrams GD, Bauer H, Sprinz $H$. Influence of the normal flora on mucosal morphology and cellular renewal in the ileum: A on mucosal morphology and cellular renew mice. Lab Invest comparison of germ

34 Meuwissen SGM, Hoitsma H, Boot H, Seldenriik CA. Pouchitis (pouch ileitis). Neth $\mathcal{F}$ Med 1989; 35: S54-S66.

35 Wong WD, Goldberg SM. The 'S' pouch. In: Lee ECG, ed. Surgery of inflammatory bowel disorders. Edinburgh Churchill Livingstone, 1987: 81-95

36 Hulten L. Workshop. Pouchitis. Int $\mathcal{f}$ Colorectal Dis 1989; 4 205-29.

37 Dixon MF. Vascular disorders, abnormalities, ischaemia vasculitis: small intestine. In: Whitehead R, ed. Gastrointestinal and oesophageal pathologv. London: Churchill Livingstone, 1989: 561-80.

38 Stern H, Walfisch S, Mullen B, McLeod R, Cohen Z. Cancer in an ileoanal reservoir: a new late complication. Gut 1990 31: 473-5.

39 Nilsson LO, Kock NG, Lindgren I, Myrvold HE, Philipson $\mathrm{BM}$, Ahren C. Morphological and histochemical changes in the mucosa of the continent ileostomy reservoir 6-10 years after its construction. Scand $\mathcal{F}$ Gastroenterol 1980; 15: 737after its construction. Scand F Gastroenterol 1980; 15: 737-

40 Dozois RR. In: Symposium. Restorative proctocolectomy with ileal reservoir. Int f Colorect Dis 1986; 1: 2-19.

41 Moskowitz RL. Symposium. Restorative proctocolectom with ileal reservoir. Int $\mathcal{F}$ Colorectal Dis 1986; 1: 2-19.

42 Ojerskog B, Kock NG, Nilsson LO, Philipson BL, Ahren C. Long-term follow-up of patients with continent ileostomies. Dis Colon Rectum 1990; 33: 184-9.

43 Heppell J, De Zubiria M, Brais M-F, et al. An assessment of the risk of neoplasia in long-term ileal reservoirs using the DMH rodent model. Dis Colon Rectum 1990; 33: 26-31. 